\title{
Wiedza na temat szpiku kostnego i jego transplantacji wśród młodzieży licealnej
}

\section{Knowledge about bone marrow and its transplant among secondary school students}

\author{
Weronika Wolińska1 ${ }^{\boxplus}$, Iwona Ewa Karpeta-Pawlak¹, Artur Kotwas², Marta Bażydło², Beata Karakiewicz² \\ ${ }^{1}$ Pomorski Uniwersytet Medyczny w Szczecinie, Zakład Nauk Humanistycznych w Medycynie, ul. Gen. Dezyderego Chłapowskiego 11, 70-103 Szczecin \\ ${ }^{2}$ Pomorski Uniwersytet Medyczny w Szczecinie, Katedra i Zakład Zdrowia Publicznego, ul. Żołnierska 48, 71-210 Szczecin \\ $\triangle$ weronika.wolinska@pum.edu.pl
}

\begin{abstract}
Introduction: The society has insufficient knowledge about bone marrow, which results in the fear of registration in the database of potential bone marrow donors. Better education in the field of bone marrow can help to attract more donors and create better prospects for patients who require transplant. The aim of this study was to assess the level of knowledge of high school students on bone marrow and its transplantation, and to determine the effectiveness of educational workshops to increase knowledge among high school students.

Materials and methods: The study was conducted in the city of Szczecin, among students of randomly selected secondary schools. The study involved 402 students - 273 females (67.91\%) and 129 males (32.09\%). A diagnostic questionnaire-based survey was carried out. A specially designed original 23-question survey was used, and it included questions about bone marrow and other issues. Under the project educational workshops were also organized in order to compare the level of knowledge
\end{abstract}

before and after the workshop. The results were statistically analyzed in PQStat.

Results: Respondents gave the most accurate answers to questions related to the definition and function of bone marrow, which could be linked with information acquired during biology lessons. The correct answer to the question concerning the anonymity and free of charge intervention of bone marrow transplantation was provided by $302(75.50 \%)$ respondents. However, respondents did not know particulars about the procedure for collecting stem cells.

Conclusions: The study demonstrated that secondary school students know very little about bone marrow and its transplant. Secondary schools can provide basic knowledge about bone marrow during biology lessons. Students do not have knowledge about the procedure in which bone marrow is collected because of the lack of access to this information and the fact that this issue is not covered by the secondary school curriculum. Keywords: bone morrow; knowledge; education.

\begin{abstract}
ABSTRAKT
Wstęp: Wiedza na temat szpiku kostnego wśród społeczeństwa nie jest wystarczająco pogłębiona, co skutkuje obawą przed rejestracją w bazach potencjalnych dawców szpiku. Edukacja na ten temat może zarówno pozwolić na pozyskanie większej liczby dawców, jak i zapewnić lepszą perspektywę dla chorych potrzebujących szpiku kostnego.

Celem pracy było poznanie poziomu wiedzy młodzieży licealnej na temat szpiku kostnego oraz jego transplantacji, a także określenie skuteczności warsztatów edukacyjnych w podnoszeniu wiedzy licealistów.

Materiały i metody: Badanie przeprowadzono na terenie Szczecina wśród uczniów losowo wybranych szkół ponadgimnazjalnych. W badaniach uczestniczyło 406 uczniów - 273 kobiety $(67,91 \%)$ i 129 mężczyzn (32,09\%). Wybraną metodą był sondaż diagnostyczny przeprowadzony za pomocą ankiety. Zastosowano autorski kwestionariusz ankiety, który składał się z 23 pytań. Ankieta zawierała m.in. pytania dotyczące wiedzy na temat szpiku kostnego. W związku z badaniami przeprowadzono również warsztaty edukacyjne w celu porównania poziomu wiedzy
\end{abstract}

przed ich realizacją i po ich zrealizowaniu. Uzyskane wyniki poddano analizie statystycznej w programie PQstat.

Wyniki: Wśród respondentów najwięcej trafnych odpowiedzi uzyskano w pytaniach dotyczących definicji i spełnianej funkcji szpiku kostnego, co mogło się wiązać z informacjami przekazywanymi podczas lekcji biologii. W pytaniu dotyczącym anonimowości i bezpłatności zabiegu, jakim jest pobieranie szpiku kostnego, prawidłową odpowiedź wskazało ponad $75 \%$ ankietowanych. Jednakże respondenci nie wiedzą, na czym polega procedura związana z pobieraniem komórek macierzystych. Wnioski: Na podstawie przeprowadzonych badań wysnuto wniosek, iż wiedza młodzieży ponadgimnazjalnej z zakresu szpiku kostnego jest mała. Edukacja w szkołach ponadgimnazjalnych na lekcjach biologii umożliwia zdobycie wiedzy dotyczącej szpiku kostnego w zakresie podstawowym. Uczniowie nie mają wiedzy na temat procedury pobierania szpiku kostnego ze względu na brak dostępu do niniejszych informacji oraz nieuwzględnienie ich w treściach programowych.

Słowa kluczowe: szpik kostny; wiedza; edukacja. 


\section{WSTĘP}

Problem związany z zachorowalnością na białaczkę dotyczy coraz większej liczby osób, co świadczy o powszechności tego zjawiska. Według danych z 2010 r. na świecie w bazach potencjalnych dawców szpiku kostnego zarejestrowanych było prawie 20 mln osób. Natomiast w Polsce w 2016 r. było ich jedynie 1055241 , co stanowi 5,28\% w skali światowej [1, 2]. Z roku na rok liczba dawców zwiększa się m.in. dzięki zaangażowaniu mass mediów. Działania promocyjne polegają na organizowaniu akcji oraz tworzeniu spotów reklamowych zachęcających do rejestracji w bazach potencjalnych dawców szpiku. Ważną rolę w propagowaniu świadomej decyzji o zostaniu dawcą szpiku pełnią osoby publiczne niezwiązane ze światem medycznym, np. aktorzy, piosenkarze.

Szpikiem kostnym nazywamy galaretowatą lub półpłynną tkankę znajdującą się w jamach kości długich nasad przestrzeni beleczkowatych. Funkcją szpiku kostnego jest wytwarzanie komórek krwi: krwinek czerwonych (erytrocytów), krwinek białych (leukocytów) oraz płytek krwi (trombocytów) $[3,4]$.

Grupą szczególnie narażoną na choroby szpiku kostnego są osoby starsze. Częściej chorują mężczyźni niż kobiety. Szpik kostny narażony jest na wiele czynników chorobotwórczych, w konsekwencji czego mogą one zaburzać wytwarzanie odpowiednich krwinek lub ich prekursorów. Zaburzenia można podzielić na: niedoborowe, niewydolnościowe oraz nowotworowe. Do najczęstszych schorzeń szpiku kostnego zalicza się tworzenie nieprawidłowych komórek, które funkcjonują w sposób upośledzony oraz źle dojrzewają. Zbyt duża ilość komórek jednego typu może zapoczątkować hamowanie tworzenia się innych typów krwinek. Przyczyną chorób szpiku mogą być zarówno niedobory krwinek, jak i żelaza, co może zaburzać proces wytwarzania krwinek czerwonych. Wymienione zaburzenia mogą powodować chłoniaki lub inne nowotwory złośliwe umiejscowione w szpiku kostnym [5, 6, 7, 8].

Dla niektórych chorych jedyną formą leczenia jest transplantacja szpiku kostnego, dlatego niezwykle ważne jest tworzenie baz potencjalnych dawców szpiku. Procedura rejestracji potencjalnych dawców szpiku jest całkowicie bezpłatna i anonimowa zarówno dla dawcy, jak i biorcy. Do kryteriów kwalifikacji dawcy zalicza się: przedział wiekowy 18-55 lat, waga minimum 50 kg lub brak dużej nadwagi (wg wskaźnika masy ciała) oraz indywidualny przegląd zdrowia $[9,10]$.

W medycynie wyróżnia się dwa sposoby pobierania komórek macierzystych: z talerza kości biodrowej oraz z krwi obwodowej. Ostateczny wybór metody zależny jest od stanu zdrowia biorcy. W przypadku pobierania szpiku z talerza kości biodrowej zabieg przeprowadzany jest przy zastosowaniu znieczulenia zewnątrzoponowego, dzięki któremu jest bezbolesny. Natomiast pobieranie szpiku kostnego drugą metodą wiąże się z bolesnością porównywalną do odczuwania bólu podczas krwiodawstwa. Pobór szpiku nie powoduje uszczerbku na zdrowiu dawcy [6]. W procesie rekonwalescencji po zabiegu regeneracja trwa 2-3 tyg. W tym czasie szpik kostny namnaża się do stanu sprzed pobrania komórek macierzystych [6].
Przeszczepianie narządów jest popierane przez Kościół katolicki. Według Katechizmu Kościoła Katolickiego transplantacja narządów ,jest czynem szlachetnym i godnym pochwały i należy do niego zachęcać, ponieważ jest przejawem wielkodusznej solidarności" [9, 10].

Analizując problem dotyczący chorób szpiku kostnego, a szczególnie jego skali występowania, należy zwrócić uwagę na proces edukacji młodzieży w szkołach. Dlatego też celem pracy było poznanie poziomu wiedzy młodzieży licealnej na temat szpiku kostnego oraz jego transplantacji, a także określenie skuteczności warsztatów edukacyjnych w podnoszeniu wiedzy licealistów.

\section{MATERIAtY I METODY}

Badanie oparte na sondażu diagnostycznym przeprowadzono na terenie Szczecina wśród uczniów szkół ponadgimnazjalnych. Dobór szkół był losowy, natomiast klasy do realizacji warsztatów edukacyjnych związanych z problematyką dotyczącą szpiku kostnego dobrano celowo. W badaniu rozdano 411 kwestionariuszy ankiety. Uzyskano zwrotność na poziomie 402 egzemplarzy, zaś w ewaluacji zwrotność wyniosła 126 egzemplarzy.

W badanej grupie liczba kobiet wyniosła 273 (67,91\%), a mężczyzn 129 (32,09\%). W 4 ankietach respondenci nie wskazali swojej płci. Średnia arytmetyczna wieku wyniosła 17,25, CI: 17,17-17,32, SD = 0,74, mediana 17, a moda 17. Rozkład wieku nie spełniał założenia normalności (ryc. 1), co potwierdzono przeprowadzonym testem Shapiro-Wilka $\left(\chi^{2}=0,827 ; p=0,000\right)$.

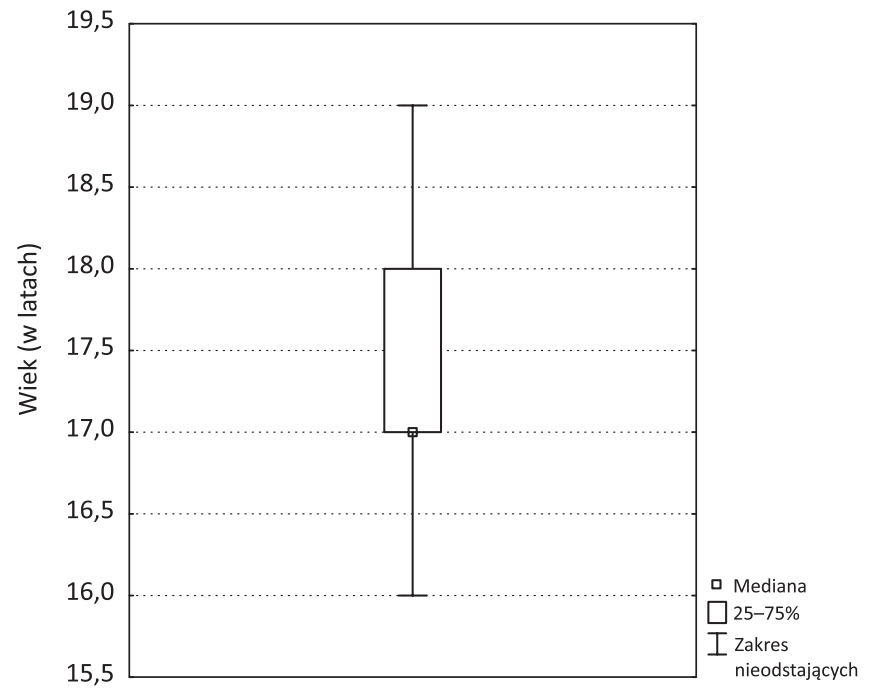

RYCINA 1. Wiek grupy badanej

W badaniu zastosowano metodę sondażu diagnostycznego, technikę ankiety, a użytym narzędziem był autorski kwestionariusz ankiety. Wypełnienie kwestionariusza było całkowicie dobrowolne i anonimowe. W badaniu wykorzystano program statystyczny PQstat, dzięki któremu możliwe było przeprowadzenie statystyki opisowej i matematycznej. 
Wyniki ukazują dane zebrane przed realizacją warsztatów edukacyjnych.

Szpik kostny został poprawnie zdefiniowany przez 257 osób (65,50\%). Funkcję szpiku kostnego poprawnie wskazało 306 ankietowanych (78\%). Na pytanie dotyczące anonimowości i bezpłatności procesu rejestracji i pobierania poprawnie odpowiedziało 302 respondentów (75,50\%). Ponad połowa respondentów wiedziała, w jakim wieku powinna być osoba, aby mogła zostać dawcą szpiku. Odnotowano niski poziom wiedzy na temat przebiegu transplantacji szpiku. Jedynie 146 badanych (36,80\%) wskazało na to, że kręgosłup nie jest miejscem z którego pobiera się komórki macierzyste. Tylko 140 osób (35,10\%) stwierdziło, że szpik kostny regeneruje się w pełni w 2-3 tyg. W badanej grupie 126 ankietowanych (31,60\%) odpowiedziało poprawnie, iż zabieg pobierania szpiku nie jest bolesny.

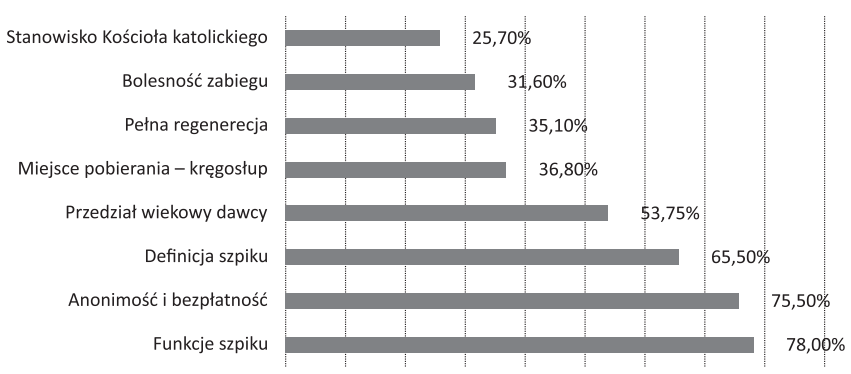

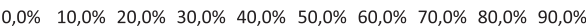

RYCINA 2. Poprawne odpowiedzi na pytania dotyczące szpiku kostnego
Zaledwie 101 respondentów (25,70\%) wiedziało o poparciu Kościoła katolickiego dla przeszczepiania narządów (ryc. 2).

Autorzy utworzyli trójstopniowy podział oceny poziomu wiedzy respondentów na temat szpiku kostnego i jego transplantacji. Można było uzyskać 0-8 pkt, gdzie jeden punkt odpowiadał jednej prawidłowo wskazanej odpowiedzi. Podział wyglądał następująco: brak wiedzy (0-4 pkt), dostateczna wiedza (5-6 pkt), dobra wiedza (7-8 pkt). Na rycinie 3 zobrazowano znajomość tematyki szpiku kostnego. Wśród respondentów brakiem wiedzy wykazały się 242 osoby $(63,44 \%)$. Jedynie 26 badanych $(8,73 \%)$ odznaczało się wiedzą na poziomie dobrym. Po przeprowadzonych warsztatach edukacyjnych zaobserwowano znaczący wzrost odsetka osób z wiedzą na poziomie dobrym oraz spadek liczby respondentów z brakiem wiedzy (ryc. 3).

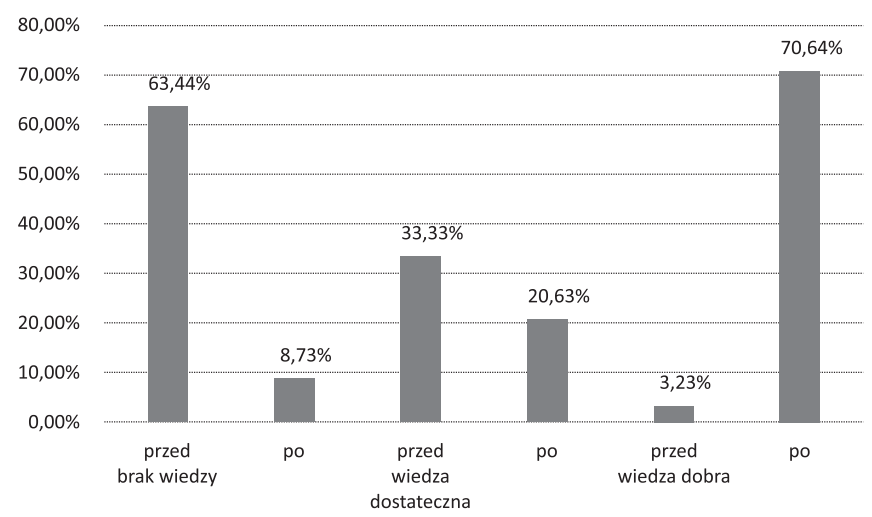

RYCINA 3. Ocena wiedzy respondentów z zakresu szpiku kostnego i jego transplantacji

TABELA 1. Związek pomiędzy poziomem wiedzy a sytuacją materialnych badanych

\begin{tabular}{|c|c|c|c|c|c|c|c|c|}
\hline \multirow{2}{*}{ Poziom wiedzy } & & \multicolumn{6}{|c|}{ Sytuacja materialna } & \multirow{2}{*}{$\begin{array}{c}\text { H Kruskala-Wallisa } \\
\text { p }\end{array}$} \\
\hline & & bardzo dobra & dobra & przeciętna & zta & bardzo zła & ogółem & \\
\hline Brak wiedzy & $\mathrm{n}$ & 11 & 72 & 114 & 52 & 6 & 255 & \multirow{7}{*}{$\begin{array}{l}H=3,798 \\
p=0,284\end{array}$} \\
\hline \multirow{2}{*}{ Wiedza dostateczna } & $\mathrm{n}$ & 3 & 37 & 71 & 21 & 2 & 134 & \\
\hline & $\%$ & $21,4 \%$ & $33,3 \%$ & $36,6 \%$ & $28,0 \%$ & $25,0 \%$ & $33,3 \%$ & \\
\hline \multirow{2}{*}{ Wiedza dobra } & $\mathrm{n}$ & 0 & 2 & 9 & 2 & 0 & 13 & \\
\hline & $\%$ & $0,0 \%$ & $1,8 \%$ & $4,6 \%$ & $2,7 \%$ & $0,0 \%$ & $3,2 \%$ & \\
\hline \multirow{2}{*}{ Ogółem } & $\mathrm{n}$ & 14 & 111 & 194 & 75 & 8 & 402 & \\
\hline & $\%$ & $100,0 \%$ & $100,0 \%$ & $100,0 \%$ & $100,0 \%$ & $100,0 \%$ & $100,0 \%$ & \\
\hline
\end{tabular}

TABELA 2. Związek pomiędzy poziomem wiedzy a płcią

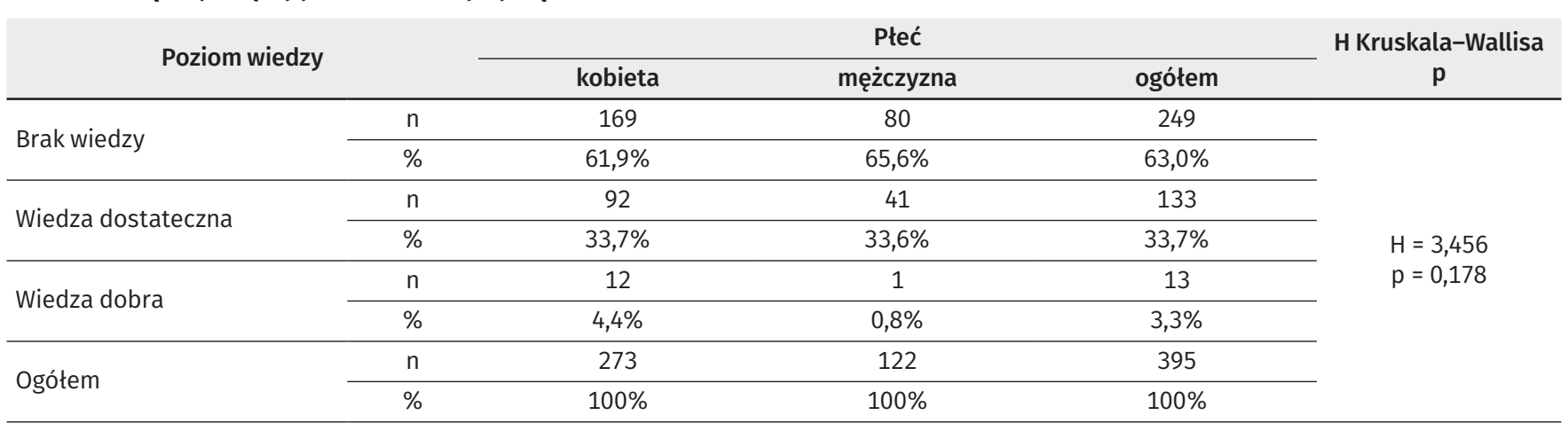


TABELA 3. Związek pomiędzy poziomem wykształcenia rodziców respondentów a wiedzą ankietowanych

\begin{tabular}{|c|c|c|c|c|c|c|c|}
\hline \multirow{2}{*}{\multicolumn{3}{|c|}{ Wyksztatcenie rodziców }} & \multicolumn{4}{|c|}{ Poziom wiedzy uczniów } & \multirow{2}{*}{ Statystyka } \\
\hline & & & brak wiedzy & wiedza dostateczna & wiedza dobra & ogółem & \\
\hline \multirow{10}{*}{ Matka } & \multirow{2}{*}{ podstawowe } & $\mathrm{n}$ & 7 & 4 & 0 & 11 & \\
\hline & & $\%$ & $63,6 \%$ & $36,4 \%$ & $0,0 \%$ & $100 \%$ & $\mathrm{H}=1,978$ \\
\hline & \multirow{2}{*}{ zawodowe } & $\mathrm{n}$ & 45 & 28 & 1 & 74 & $p=0,372$ \\
\hline & & $\%$ & $60,8 \%$ & $37,8 \%$ & $1,4 \%$ & $100 \%$ & \\
\hline & \multirow{2}{*}{ średnie } & $\mathrm{n}$ & 35 & 24 & 4 & 63 & \\
\hline & & $\%$ & $55,6 \%$ & $38,1 \%$ & $6,3 \%$ & $100 \%$ & rho $=-0,053$ \\
\hline & \multirow{2}{*}{ wyższe } & $\mathrm{n}$ & 148 & 69 & 8 & 225 & $p=0,310$ \\
\hline & & $\%$ & $65,8 \%$ & $30,7 \%$ & $3,6 \%$ & $100 \%$ & \\
\hline & \multirow{2}{*}{ Ogółem } & $\mathrm{n}$ & 235 & 125 & 13 & 373 & \\
\hline & & $\%$ & $63,0 \%$ & $33,5 \%$ & $3,5 \%$ & $100 \%$ & \\
\hline \multirow{10}{*}{ Ojciec } & \multirow{2}{*}{ podstawowe } & $n$ & 9 & 2 & 0 & 11 & \\
\hline & & $\%$ & $81,8 \%$ & $18,2 \%$ & $0,0 \%$ & $100,0 \%$ & $H=0,685$ \\
\hline & \multirow{2}{*}{ zawodowe } & $\mathrm{n}$ & 82 & 47 & 3 & 132 & $p=0,710$ \\
\hline & & $\%$ & $62,1 \%$ & $35,6 \%$ & $2,3 \%$ & $100,0 \%$ & \\
\hline & \multirow{2}{*}{ średnie } & $\mathrm{n}$ & 26 & 13 & 2 & 41 & \\
\hline & & $\%$ & $63,4 \%$ & $31,7 \%$ & $4,9 \%$ & $100,0 \%$ & rho $=0,013$ \\
\hline & \multirow{2}{*}{ wyższe } & $n$ & 119 & 61 & 7 & 187 & $p=0,796$ \\
\hline & & $\%$ & $63,6 \%$ & $32,6 \%$ & $3,7 \%$ & $100,0 \%$ & \\
\hline & \multirow{2}{*}{ Ogółem } & $\mathrm{n}$ & 236 & 123 & 12 & 371 & \\
\hline & & $\%$ & $63,6 \%$ & $33,2 \%$ & $3,2 \%$ & $100,0 \%$ & \\
\hline
\end{tabular}

W pracy zbadano zależność pomiędzy poziomem wiedzy ankietowanych a subiektywną oceną sytuacji materialnej w domu respondentów. Na podstawie uzyskanych danych zaobserwowano, iż osoby odznaczające się przeciętną sytuacją materialną miały największą wiedzę z zakresu szpiku i jego transplantacji $(n=9 ; 4,6 \%)$. Związek pomiędzy poziomem wiedzy a sytuacją materialną nie był istotny statystycznie ( $\mathrm{H}=3,798 ; \mathrm{p}=0,284 ;$ tab. 1 ).

Sprawdzono zależność między poziomem wiedzy badanej młodzieży a płcią. Kobiety ( $\mathrm{n}=12 ; 4,4 \%)$ odznaczały się większą wiedzą niż mężczyźni ( $\mathrm{n}=1 ; 0,8 \%)$. Analizowane zmienne nie wykazały istotności statystycznej $(\mathrm{H}=3,456 ; \mathrm{p}=0,178$, tab. 2).

Zbadano związek pomiędzy poziomem wykształcenia rodziców respondentów a wiedzą ankietowanych. Nie zauważono istotnych statystycznie powiązań między tymi zmiennymi $(H=1,978 ; p=0,372, H=0,685 ; p=0,710$, tab. 3$)$.

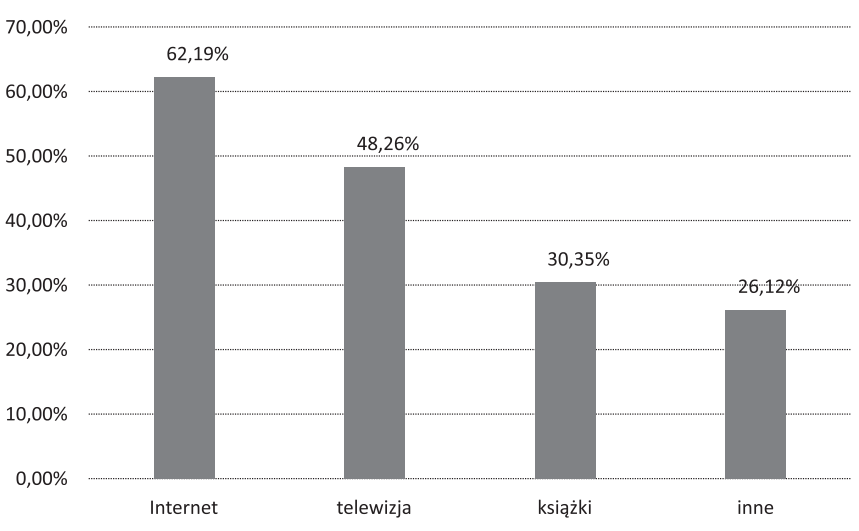

RYCINA 4. Źródła wiedzy
Dla autorów niniejszego artykułu istotne były również najczęstsze źródła informacji na temat szpiku kostnego i jego transplantacji. Badani wskazywali następujące odpowiedzi: Internet ( $\mathrm{n}=250 ; 62,19 \%)$, telewizja ( $\mathrm{n}=194 ; 48,26 \%)$, książki ( $n=122 ; 30,35 \%)$ oraz inne $(n=105 ; 26,12 \%)$. W przypadku wybrania odpowiedzi „inne” respondenci zostali poproszeni o uzupełnienie odpowiedzi; padały m.in. następujące warianty: rodzina, szkoła, bajki edukacyjne, ulotki informacyjne, filmy. Najpowszechniejszym źródłem wiedzy był Internet (ryc. 4).

\section{DYSKUSJA}

W ostatnich latach odnotowano wzrost zainteresowania transplantacją szpiku kostnego, jednakże w świecie medycznym wciąż niewystarczająca jest liczba publikacji naukowych na ten temat. W medycynie transplantacyjnej zauważalny jest ogromny postęp, ale świadomość społeczna wciąż jest niska. Spowodowane to może być niewystarczającą wiedzą na temat procedury pobierania szpiku kostnego, co w konsekwencji prowadzi do strachu przed zabiegiem, obaw o własne bezpieczeństwo, lęku o przebieg rekonwalescencji i wielu wątpliwości.

W niniejszym badaniu autorzy podjęli próbę poznania poziomu wiedzy z zakresu przeszczepiania szpiku kostnego. Z zebranych danych wynika, iż młodzież w wieku ponadgimnazjalnym nie wie jak wygląda procedura pobierania szpiku kostnego. W badaniu Gościniak i Wójty-Kempy [11] wykazano, że respondenci kierują się powszechnie panującymi mitami. Uważają, że szpik kostny pobiera się z kręgosłupa, a sam proces 
pobierania jest bolesny. W grupie badanych $2 / 3$ osób nie poddałoby się temu zabiegowi z powodu przekonania o jego bolesności. Jedynie w przypadku oddania szpiku dla członka rodziny badani byliby bardziej skłonni poddać się zabiegowi. Podobna grupa badanych (2/3) stwierdziła, że szpik kostny regeneruje się bardzo długo lub wcale. Zbliżone wyniki uzyskano w badaniu własnym.

Według Makary-Studzińskiej i Celińskiego [12] Kościół katolicki popiera przeszczepianie narządów. W badaniu własnym również poruszono ten aspekt. Makara-Studzińska i Celiński [12] zaobserwowali pozytywny wpływ mediów na proces związany z transplantacją. W badaniu własnym dostrzeżono zaletę Internetu jako źródła pozyskiwania wiedzy o przeszczepianiu szpiku.

Gościniak i Wójta-Kempa [11] ujawniły powody braku chęci rejestracji w bankach dawców. Zaliczyli do nich m.in.: brak zainteresowania tematyką szpiku kostnego, istotny wpływ działań emocji i blokujących stereotypów na chęć bycia dawcą. Gościniak i Wójta-Kempa [11] zauważyły, że istnieje potrzeba wprowadzenia działań edukacyjnych z problematyką obejmującą przeszczepianie szpiku kostnego. $\mathrm{W}$ badaniu własnym zastosowano warsztaty edukacyjne i zauważono ich pozytywny wpływ.

Radunz i wsp. [13] wykazali, że pozyskana wiedza jest kluczem do pozostania potencjalnym dawcą szpiku kostnego. Autorzy wprowadzili programy edukacyjne o tematyce transplantacji na terenie Niemiec. Podobne działania zastosowano w niniejszym badaniu.

\section{WNIOSKI}

1. Wiedza młodzieży ponadgimnazjalnej z zakresu szpiku kostnego jest niska. Z tego powodu konieczne jest wdrażanie działań mających na celu podnoszenie aktualnego stanu wiedzy na temat transplantacji szpiku kostnego.

2. Pomiędzy poziomem zamożności respondentów a poziomem ich wiedzy nie wykazano zależności istotnych statystycznie, które mogłyby wpływać na sposób udzielania odpowiedzi. Jak również w przypadku związku pomiędzy płcią ankietowanych a poziomem wiedzy. Poziom wykształcenia rodziców uczniów nie wskazuje na związek z ich wiedzą.

3. Warsztaty edukacyjne podniosły poziom wiedzy młodzieży ponadgimnazjalnej. Wskazuje to na fakt, iż niezwykle ważną rolę przypisać można działaniom związanym z kształceniem młodzieży w kwestii przeszczepiania szpiku kostnego. Wzrost wiedzy może przyczynić się do zwiększenia odsetka osób chcących pozostać potencjalnymi dawcami szpiku kostnego.

4. Należy wykorzystać Internet do przekazywania informacji i prowadzenia działań edukacyjnych na temat transplantacji szpiku kostnego.

\section{PIŚMIENNICTWO}

1. Styczyński J. Bezpieczeństwo dawców krwiotwórczych komórek macierzystych. Hematologia 2012;3(1):58-65.

2. Fundacja DKMS. https://www.dkms.pl/pl (7.03.2017).

3. Kopeć-Szlęzak J. Krwiotwórcza komórka macierzysta w niszy szpikowej. J Transf Med 2011;4(3):129-35.

4. Zaucha JM, Taszner M, Baran W, Knopińska-Posłuszny W, Hellmann A. Znaczenie transplantacji szpiku w leczeniu chorych z ostrą białaczką szpikową. Ann Acad Med Gedan 2006;36:211-23.

5. Hołowiecki J. Bone marrow and blood cell transplantation activity in Poland. Acta Haematol Pol 1997;28(Suppl 2):154-63.

6. Zembala M. Zasady pobierania i przeszczepiania narządów i tkanek do transplantacji w ujęciu Europejskiej Konwencji Bioetycznej. Kardiochir Torakochir Pol 2009;6(4):407-11.

7. Markiewicz M, Kyrcz-Krzemień S. Allogeniczne przeszczepienie komórek krwiotwórczych: stan obecny i perspektywy rozwoju. Post Nauk Med 2011;24(6):479-85

8. Marosz-Rudnicka A, Mika-Witkowska R, Graczyk-Pol E, Długokęcka A, Rogatko-Koroś M, Nowak J. Immunogenetyczny dobór dawców allogenicznych krwiotwórczych komórek macierzystych. Hematologia 2012;3(3):211-20.

9. Rowiński W, Wałaszewski J. Etyczno-prawne problemy przeszczepiania narządów. Med Dypl 1995;4(4):17-20.

10. Majchrowicz B. Moralne problemy transplantacji. Acta Med Premisliensia 2010;33:93-6.

11. Gościniak M, Wójta-Kempa M. Wiedza i postawy studentów wrocławskich uczelni na temat transplantacji szpiku kostnego. Piel Zdr Publ 2011;1(1):27-34.

12. Makara-Studzińska M, Celiński R. Poziom wiedzy pielęgniarek na temat medycyny transplantacyjnej. Zdrow Publiczne 2009;119(4):408-13.

13. Radunz S, Juntermanns B, Heuer M, Frühauf NR, Paul A, Kaiser GM. The effect of education on the attitude of medical students towards organ donation. Ann Transplant 2012;17(1):140-4. 